\title{
Chemical composition of selected marine microalgae, with emphasis on lipid and carbohydrate production for potential use as feed resources
}

\author{
Kjell Inge Reitan ${ }^{1}(1) \cdot$ Gunvor Øie ${ }^{2} \cdot$ Håvard Jørgensen ${ }^{3} \cdot$ Xinxin Wang ${ }^{1,4}$
}

Received: 4 May 2021 / Revised and accepted: 2 August 2021 / Published online: 14 September 2021

(C) The Author(s) 2021

\begin{abstract}
Marine microalgae are a promising sustainable source of lipids, omega-3 fatty acids, and carbohydrates. Selected microalgae species belonging to the Bacillariophyceae, Haptophyceae, Eustigmatophyceae, and Prasinophyceae were characterised for cellular content of carbon and nitrogen, and for production yields of lipids, fatty acids, total carbohydrates, and $\beta$-glucans. Carbon and nitrogen content showed a hyperbolic decrease with increasing cell numbers for Chaetoceros calcitrans, $C$. muelleri, Skeletonema costatum, Tetraselmis sp., and Nannochloropsis oculata. Cultures of Pavlova lutheri and Tisochrysis lutea showed an increase in carbon content per cell, but a decrease in nitrogen content. The total lipid content of $C$. muelleri, C. calcitrans, $N$. oculata, and T. lutea increased with decreasing relative growth rate; however, the highest productivity of lipids was found in T. lutea grown at $40 \%$ of the maximum specific growth rate. The highest content of eicosapentaenoic acid was found in C. muelleri, C. calcitrans, and N. oculata, and the highest content of docosahexaenoic acid was found in $T$. lutea. The $\beta$-glucan fraction of the carbohydrates was highest in C. muelleri and C. calcitrans and was very low in $N$. oculata. Out of the species investigated, $C$. muelleri had the highest production yield of $\beta$-glucans, obtained when cultivated at a $40 \%$ relative growth rate.
\end{abstract}

Keywords Marine microalgae $\cdot$ Lipids $\cdot$ Fatty acids $\cdot$ Carbohydrates $\cdot \beta$-glucans $\cdot$ Cultivation

\section{Introduction}

Microalgae are a natural source of n-3 fatty acids, especially eicosapentaenoic acid (EPA) and docosahexaenoic acid (DHA), which are accumulated in the marine food chain (Reitan et al. 1994, 1997; Brown et al. 1997; Shah et al. 2018). The chemical composition of microalgae varies with species and classes, and the lipid content typically ranges from 10 to $60 \%$ of dry matter (Reitan et al. 1994; Brown et al. 1997; Chiu et al. 2009; Rodolfi et al. 2009; Doan et al. 2011; Wang et al. 2019). In addition, growth conditions such

Kjell Inge Reitan

Kjell.I.Reitan@ntnu.no

1 Department of Biology, Norwegian University of Science and Technology (NTNU), N-7491 Trondheim, Norway

2 SINTEF Oceans, N-7465 Trondheim, Norway

3 BIOMAR, Havnegata 9, Pirsenteret, N-7010 Trondheim, Norway

4 Present Address: Nofima AS, N-9291 Troms $\emptyset$, Norway as nutrient limitation and light intensity have been observed to influence significantly the growth rate and chemical composition of various microalgae species (Reitan et al. 1994; Tzovenis et al. 2003; Guedes et al. 2010; Vu et al. 2016). Temperature was found to have a pronounced effect on the growth rate, lipid content, and fatty acid profiles of microalgae (Roleda et al. 2013; Chaisutyakorn et al. 2018). The maximum specific grow rate increases with increasing temperatures to the optimal growth temperature, whereas it decreases for increasing temperatures above this point (Converti et al. 2009). Microalgae also differ in carbohydrate composition, again depending on both species and cultivation conditions (Pernet et al. 2003; Størseth et al. 2005). Microalgae species have been shown to accumulate carbohydrates as well as lipids when cultivated under nitrogen limitation (Harrison et al. 1990; Yang et al. 2013). The carbohydrates in microalgae may contain a high fraction of $\beta$-1,3-glucan (Størseth et al. 2004), and several studies suggest that $\beta-1,3$-glucan may act as an immunostimulant in fish and shellfish (Dahlmo et al. 1996; Chang et al. 2000; Vetvicka et al. 2013). 
Because of their balanced composition of proteins and lipids (Brown et al. 1997), microalgae have been suggested as an alternative future feed resource, especially for use in aquafeed (Chauton et al. 2014). De novo synthesis of n-3 fatty acids can only take place in plant cells, and long-chain polyunsaturated fatty acids, such as EPA (Eicosapentaenoic acid) and DHA (Docosahexaenoic acid), are frequently found in high concentrations in marine microalgae (Brown et al. 1997; Patil et al. 2006; Shah et al. 2018). This makes marine microalgae a promising source for fish feed (Tacon 1996; Carter et al. 2003; Burr et al. 2011; Skrede et al. 2011; Sørensen et al. 2016). A further increase in the aquaculture production would require a supply of alternatives to fish meal and fish oil (Chauton et al. 2014).

The aim of this study was to provide comprehensive information on variation in cellular contents of carbon, nitrogen and phosphorous during the growth cycle of seven microalgae species in batch cultures. Furthermore, four species with potential for use as a feed resource were selected and cultivated at three different growth rates in semi-continuous culture in order to characterise the content of total lipids, fatty acids, carbohydrates, and $\beta$-glucans. The productivity of the different compounds in the selected four microalgae species was also evaluated. The chemical composition of the microalgae was reviewed for potential use as a feed resource.

\section{Materials and methods}

\section{Culture method for microalgae}

The following microalgae were used: the Bacillariophyceae Chaetoceros muelleri Lemmermann (CCAP, strain 1010/3), Chaetoceros calcitrans (Paulsen) H.Takano (CCMP strain 1315), and Skeletonema costatum (Greville) Cleve 1873, clone Skel-5, isolated from the Trondheimsfjord (Myklestad 1974); the Haptopyceae Pavlova lutheri (Droop) Green (CCMP strain 1325) and Tisochrysis lutea El M.Bendif \& I.Probert (Tahitian) (CCAP strain 927/14); the Eustigmatophyceae Nannochloropsis oculata (Droop) D.J. Hibberd (CCAP strain 849/1); and the Prasinophyceae Tetraselmis sp. (own isolate). They were grown in 1-L glass cylinders. The cultures were grown at five different temperatures $(16,20$, 24,27 , and $32{ }^{\circ} \mathrm{C}$ ) to determine the effect of temperature on the growth rate. The microalgae were cultivated in batch cultures and continuously illuminated (Phillips TLD 36 W/33 and Phillips TL $40 \mathrm{~W} / 55$ ) at an irradiance of 70-90 $\mu \mathrm{mol}$ photons $\mathrm{m}^{-2} \mathrm{~s}^{-1}$ at the culture surface. The cultures were aerated with filtered air with added $0.1 \% \mathrm{CO}_{2}$ using a purge Rotameter model 10A 6100. The F/2 growth medium (Guillard and Ryther 1962) was prepared using sand filtered and particle filtered (pore size of $1 \mu \mathrm{m}$ ) seawater taken from a depth of $70 \mathrm{~m}$ and autoclaved before use.
The increase in biomass of the microalgae cultures was monitored by sampling of $5 \mathrm{~mL}$ volumes for regular optical density measurements using a spectrophotometer at a wavelength of $750 \mathrm{~nm}$. The specific growth rate $\left(\mu\right.$, day $\left.^{-1}\right)$ of the batch cultures was calculated as

$\mu=\ln \left(N_{t} / N_{0}\right) / t$

where $N_{0}$ is the biomass at time $t_{0}$, and $N_{t}$ is the biomass at time $t$. The maximum specific growth rate $\left(\mu_{\max }, \mathrm{day}^{-1}\right)$ was calculated in the initial exponential growth phase before the growth started to decline, when $\ln (\mathrm{N})$ versus time was linear.

The cell densities of the cultures were estimated using a Bürkner chamber and counted in microscope at $100 \times$ magnification.

Cultures of C. muelleri, C. calcitrans, N. oculata, and T. lutea were then grown semi-continuously at $20{ }^{\circ} \mathrm{C}$ in $200-\mathrm{L}$ Plexiglas cylinders at the same irradiance as for batch cultivation for determination of content and productivity of total lipids, fatty acids, carbohydrates, and $\beta$-glucans. The individual cultures were grown until steady state and each culture continued in steady state for 4-5 days (Kilham 1978) at dilution rates that corresponded to 4,40 , and $60 \%$ relative growth rate ( $\% \mu$ of $\mu_{\max }$ ). The cultures were sampled when the biomass of the cultures was in a steady state, meaning that the biomass did not vary by more than $5 \%$ between days.

\section{Chemical analysis}

The carbon, nitrogen, and phosphorous content of algae cells was analysed in batch cultures $\left(20^{\circ} \mathrm{C}\right)$ for all species. Precise volumes of the microalgae cultures were filtered using Whatman GF/F filters in six replicates for each culture at each sampling time during the growth phase of individual cultures: Three filters were used to measure carbon and nitrogen content. The filters were dried at $60{ }^{\circ} \mathrm{C}$ for $24 \mathrm{~h}$ and analysed with a Carlo Erba element analyser, model 1106, with acetanilide as standard. Phosphorus was analysed as described by Koroleff (1976) in the three remaining filter replicates.

Biomass for analysing the total lipids, fatty acids, carbohydrates, and $\beta$-glucans was harvested when the semicontinuous cultures had reached the steady state. Volumes of $2 \mathrm{~L}$ from each culture were harvested at dilution time during steady state and centrifuged at 3000-5000 rpm for 15 min (Wifug $400 \mathrm{E}$, and Heraeus Cryophuge 8000). The biomasses were frozen at $-80{ }^{\circ} \mathrm{C}$ under a $\mathrm{N}_{2}$ atmosphere before further analysis. The total lipid content was analysed gravimetrically $(n=2-3)$ after extraction by a modified Bligh and Dyer (1959) method as described by Rainuzzo et al. (1994). The fatty acid methyl esters were prepared and analysed as described by Rainuzzo et al. (1994) using a Carlo Erba HRGC 5160 gas chromatograph equipped with a SP-2330 glass capillary column with an on-column 
injection and flame ionization detector. The fatty acids were identified and quantified by comparison with known standards (NU-Chek Prep, USA) and use of response factors to internal standard (21:0). The total carbohydrate content was analysed using the phenol-sulphuric acid method (Dubois et al. 1956), and the $\beta$-glucan content was analysed using a method described by Myklestad and Haug (1972). The method is based on extraction with $0.1 \mathrm{~N}$ sulphuric acid, which omits the polysaccharides.

The productivity of the total lipid, fatty acid, carbohydrate, and $\beta$-glucan content of the biomass was calculated as

$P=$ Content $* V$

where Content is the weight of the different chemical compounds per litre, and $V$ is the daily harvested volume of the culture.

\section{Statistical analysis}

Means \pm standard errors of the means are given throughout the text, tables, and graphs. Means were tested statistically using one-way ANOVA, followed by a Student-Newman-Keuls test using SigmaPlot for Windows version 13.0 (Systat Software Inc., USA). The 5\% confidence level was used throughout the experiment.

\section{Results}

\section{Growth parameters}

The maximum specific growth rates of the seven microalgae investigated varied with the temperature (Fig. 1). The optimum growth temperature is the temperature that gives the highest maximum growth rate, and highest maximum specific growth rate of $C$. calcitrans and $N$. oculata was observed at $16{ }^{\circ} \mathrm{C}$, for $S$. costatum at $20{ }^{\circ} \mathrm{C}$, while Tetraselmis sp., C. muelleri, P. lutheri, and T. lutea obtained highest maximum specific growth rates at $24^{\circ} \mathrm{C}$. All species investigated showed decreased growth rates at temperatures above $24{ }^{\circ} \mathrm{C}$ and no growth at $32{ }^{\circ} \mathrm{C}$.

The content of carbon and nitrogen per cell of each of the seven microalgae species grown in batch cultures is shown in Fig. 2. Both the carbon and nitrogen content per cell showed a hyperbolic decrease with increasing cell numbers for $C$. calcitrans, C. muelleri, S. costatum, Tetraselmis sp., and $N$. oculata. For $P$. lutheri and T. lutea, the carbon content per cell hyperbolically increased with increasing cell numbers, while the nitrogen content per cell decreased with increasing cell numbers.

The nitrogen to carbon ratio (N/C ratio) decreased in all algae species, except in $N$. oculata, where the ratio was roughly similar at all cell densities (Figs. 2). The reduced

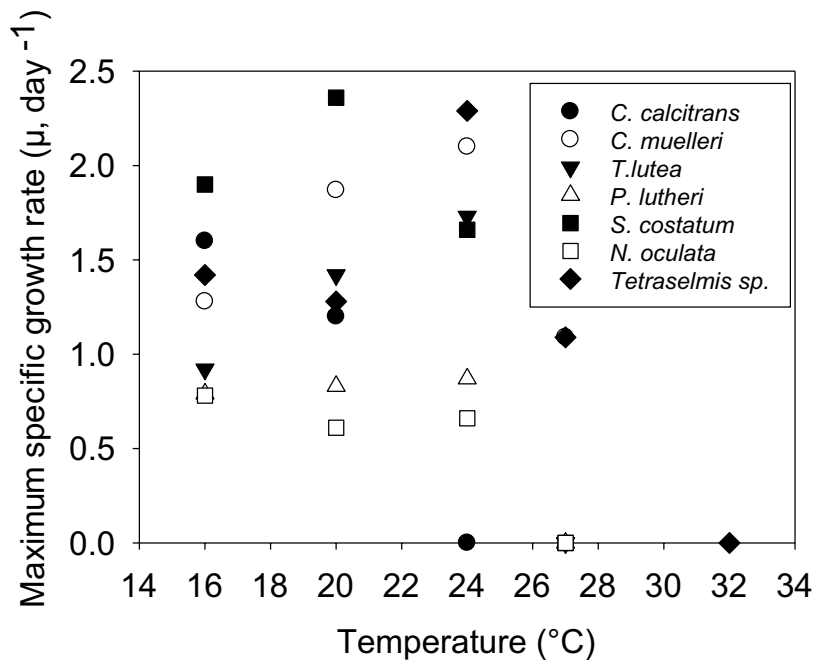

Fig. 1 The maximum specific growth rate $\left(\mu_{\max }\right)$ of the seven microalgae species grown at different cultivation temperatures

$\mathrm{N} / \mathrm{C}$ ratio with increasing cell density shows that the nitrogen content was reduced more than the carbon content when the cultures grew and the cell density increased. In the stationary phase, at high cell densities, the N/C weight ratio varied between 0.051 (for T. lutea) and 0.126 (for C. calcitrans; Fig. 3), being significantly higher for the Bacillariophyceae than for the other algae groups. The $\mathrm{P} / \mathrm{C}$ ratio at the stationary growth phase varied between 0.004 (P. lutheri, T. lutea, and N. oculata) and 0.011 (C. calcitrans; Fig. 3). The N/P ratios at the stationary phase ranged from 10.7 to 18.0.

\section{Lipids and fatty acids}

The total lipid content for all four microalgae species increased with reduced relative growth rate in semi-continuous cultures, meaning that the lipid content was highest in cultures with the strongest growth limitation for all species investigated (Fig. 4). The highest lipid content was found in $N$. oculata, at $335 \mathrm{mg} \mathrm{g}^{-1} \mathrm{DW}$ at $4 \%$ relative growth rate. Somewhat lower lipid content was observed in C. muelleri and T. lutea, at 313 and $290 \mathrm{mg} \mathrm{g}^{-1} \mathrm{DW}$, respectively. The fatty acids accounted for $40 \%$ of the total lipids on average, without any systematic variation between species or growth conditions. The variation in total lipid content of the microalgae suggests that the species investigated stored lipids while the growth was limited.

\section{Fatty acid composition}

The diatoms $C$. calcitrans and $C$. muelleri had relatively similar fatty acid profiles, with high content of 14:0, 16:0, 16:1, and 20:5 n-3, and somewhat lower content of 16:3 (Table 1). Chaetoceros muelleri also had a significantly 

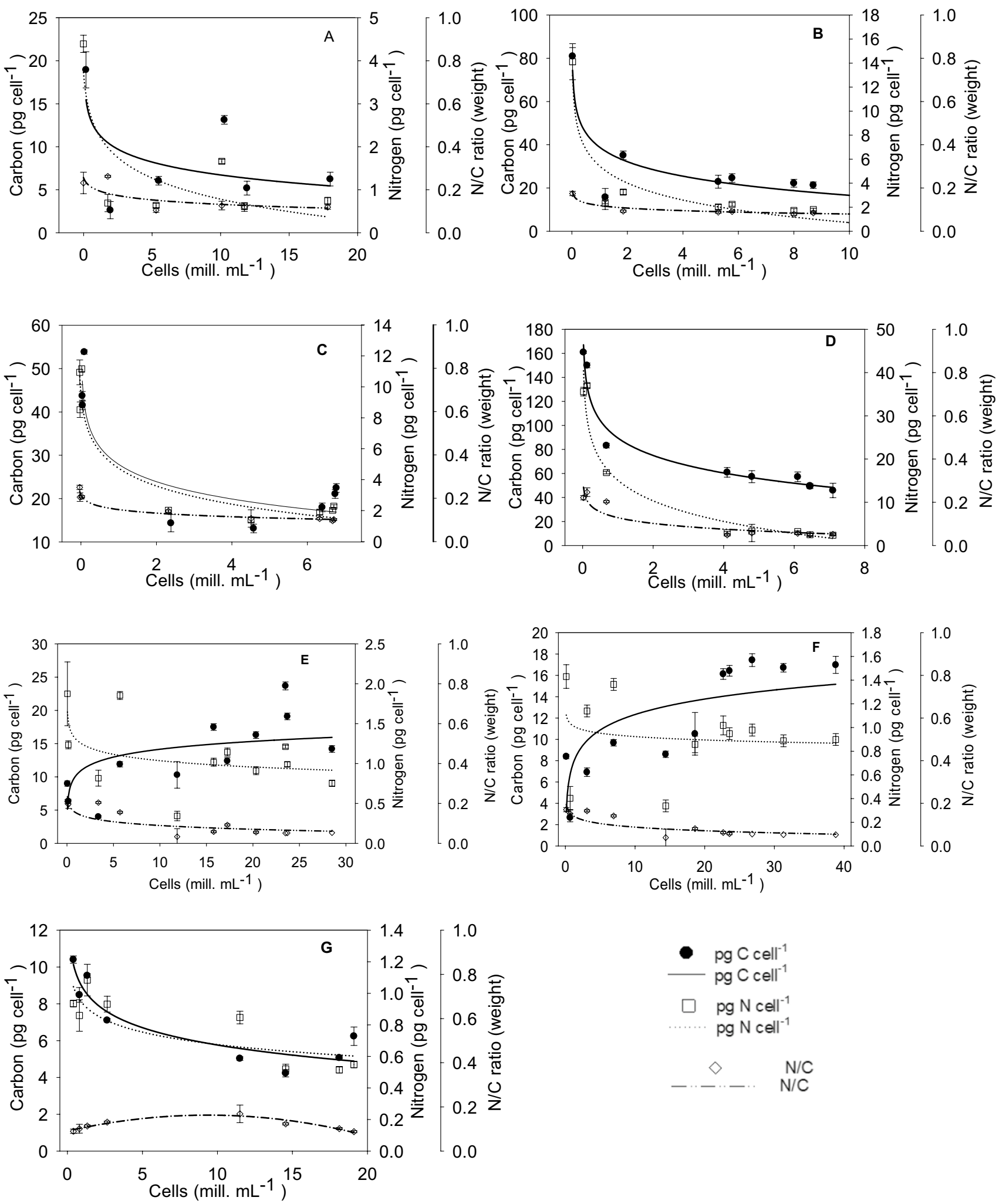

Fig. 2 Content of carbon $\left(\mathrm{C}, \mathrm{pg}_{\text {cell }}{ }^{-1}\right)$ and nitrogen $\left(\mathrm{N}, \mathrm{pg}\right.$ cell $\left.{ }^{-1}\right)$ per algae cells and the N/C weight ratio at increasing cell density of the culture of A C. calcitrans, B C. muelleri, C S. costatum, D Tetraselmis sp., E T. lutea, F P. lutheri, and G N. oculata. Means with SE bars ( $n=3)$ 
Fig. 3 The average $\mathrm{N} / \mathrm{C}, \mathrm{P} / \mathrm{C}$, and N/P weight ratios of the seven microalgae species sampled at the stationary phase. Means with SE bars $(n=3)$. Different letters indicate significant differences $(p<0.05)$

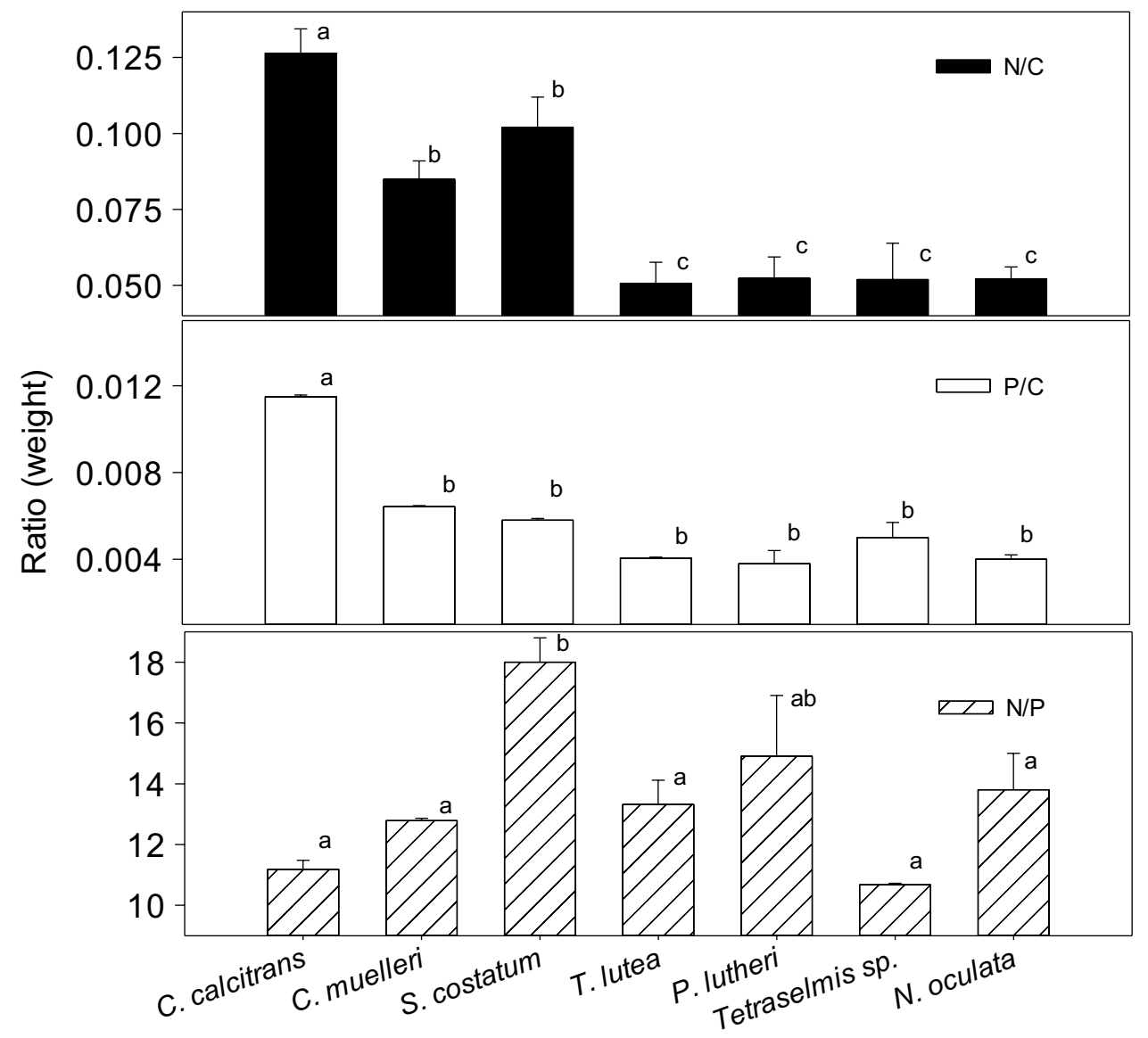

Fig. 4 Content of fatty acids ant total lipids of the microalgae cultivated by semi-continuous culture at different relative growth rates $(4 \%, 40 \%$, and $60 \%$ of $\left.\mu_{\max }\right)$. Means with SE bars $(n=2-3)$

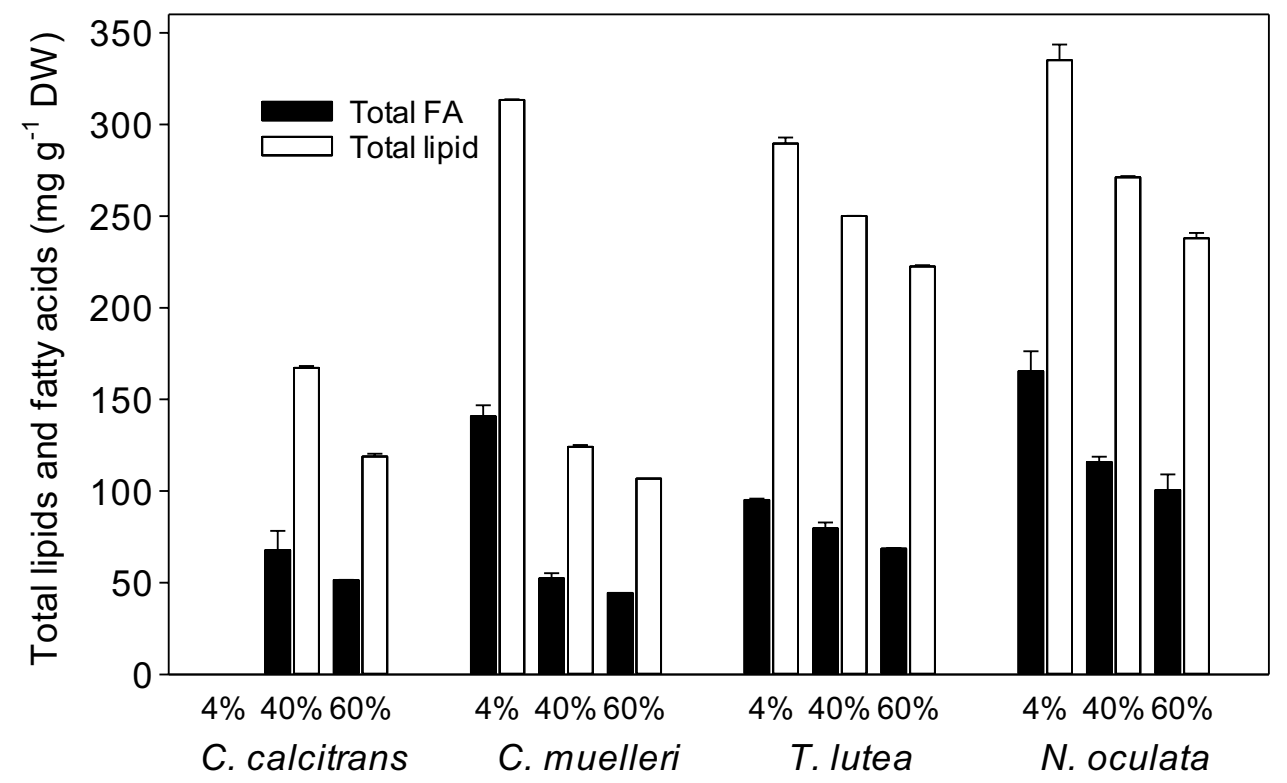

higher content of 20:4 n-6 compared to $C$. calcitrans. The fatty acid composition of $T$. lutea was dominated by $14: 0,16: 0,16: 1,18: 1$ n-9, 18:3 n-3, 18:4 n-3, and 22:6 n-3. Nannochloropsis oculata had high content of 14:0, 16:0, 16:1, 20:4 n-6, and 20:5 n-3.

The reduction in specific growth rate from 60 to $4 \%$ in C. muelleri resulted in higher relative content of 16:0 and 
Table 1 Fatty acid content $\left(\mathrm{mg} \mathrm{g}^{-1} \mathrm{DW}\right)$ in microalgae grown at different relative growth rate $\left(4 \% .40 \%\right.$, and $60 \%$ of $\left.\mu_{\max }\right)$. Mean \pm SE of two or three replicates $(C$. mиelleri at $60 \%$ only $n=1)$. Open is not detected or $<0.1$. Asterisks indicate significant difference within species

\begin{tabular}{|c|c|c|c|c|c|c|c|c|c|c|c|}
\hline \multirow[t]{3}{*}{ Fatty acid } & \multirow{2}{*}{\multicolumn{2}{|c|}{$\frac{\text { Bacillariophyceae }}{\text { C. calcitrans }}$}} & \multirow{2}{*}{\multicolumn{3}{|c|}{ C. muelleri }} & \multicolumn{3}{|c|}{ Prymnesiophyceae } & \multicolumn{3}{|c|}{ Eustigmatophyceae } \\
\hline & & & & & & \multicolumn{3}{|l|}{ T. lutea } & \multicolumn{3}{|l|}{ N. oculata } \\
\hline & $40 \%$ & $60 \%$ & $4 \%$ & $40 \%$ & $60 \%$ & $4 \%$ & $40 \%$ & $60 \%$ & $4 \%$ & $40 \%$ & $60 \%$ \\
\hline $14: 00$ & $7.1 \pm 0.4$ & $4.4 \pm 0.1 *$ & $11.8 \pm 1.3$ & $4.8 \pm 0.6^{*}$ & 3.2 & $16.0 \pm 3.2$ & $12.2 \pm 0.2$ & $9.7 \pm 1.2$ & $10.4 \pm 0.9$ & $5.5 \pm 0.1 *$ & $5.6 \pm 0.2 *$ \\
\hline $16: 00$ & $7.9 \pm 0.1$ & $6.8 \pm 0.1 *$ & $35.2 \pm 4.5$ & $11.3 \pm 2.0 *$ & 8.9 & $1.4 \pm 0.1$ & $4.6 \pm 4.9$ & $7.5 \pm 0.1$ & $35.6 \pm 8.6$ & $18.9 \pm 0.6^{*}$ & $17.2 \pm 2.8 *$ \\
\hline 18:00 & $0.2 \pm-$ & $0.2 \pm 0.1$ & $2.6 \pm 0.1$ & $1.0 \pm 0.1 *$ & 0.6 & $0.2 \pm 0.1$ & $4.0 \pm 5.4$ & $0.3 \pm 0.1$ & $0.9 \pm 0.1$ & $0.2 \pm 0.1$ & $0.3 \pm 0.1$ \\
\hline $20: 00$ & $0.1 \pm 0.1$ & $0.1 \pm 0.1$ & $0.2 \pm 0.1$ & $0.1 \pm 0.1$ & & $0.1 \pm 0.1$ & $0.1 \pm 0.1$ & $0.1 \pm 0.1$ & $0.1 \pm 0.1$ & & \\
\hline $22: 00$ & & $0.1 \pm 0.1$ & & & & $0.1 \pm 0.1$ & & & & & \\
\hline $16: 01$ & $13.5 \pm 1.5$ & $15.1 \pm 1.0$ & $42.6 \pm 4.5$ & $15.1 \pm 2.3^{*}$ & 15 & $14.2 \pm 0.2$ & $7.4 \pm 1.1^{*}$ & $3.2 \pm 0.4^{*}$ & $36.3 \pm 6.9$ & $26.6 \pm 2.2$ & $23.9 \pm 4.3$ \\
\hline $18: 1 \mathrm{n}-9$ & $0.4 \pm 0.1$ & $0.4 \pm 0.1$ & $1.2 \pm 0.1$ & $0.4 \pm 0.1$ & 0.3 & $12.1 \pm 0.1$ & $4.7 \pm 4.5$ & $8.3 \pm 0.1$ & $9.5 \pm 0.3$ & $1.5 \pm 0.1 *$ & $2.3 \pm 0.4 *$ \\
\hline $18: 1 \mathrm{n}-7$ & $0.9 \pm 0.1$ & $0.9 \pm 0.1$ & $2.6 \pm 0.1$ & $0.5 \pm 0.1$ & 0.3 & $2.1 \pm 0.1$ & $1.0 \pm 1.2$ & $1.2 \pm 0.1$ & $1.4 \pm 0.3$ & $0.8 \pm 0.1$ & $0.7 \pm 0.2$ \\
\hline $22: 01$ & & $0.1 \pm 0.1$ & $0.5 \pm 0.1$ & $0.1 \pm 0.1$ & & & & & & & \\
\hline $16: 2 n-4$ & $2.9 \pm 0.1$ & $1.9 \pm 0.1$ & $4.6 \pm 1.7$ & $2.1 \pm 1.6$ & 0.8 & $0.6 \pm 0.1$ & $1.0 \pm 0.1$ & $0.6 \pm 0.1$ & $0.6 \pm 0.1$ & $1.2 \pm 0.1$ & $0.9 \pm 0.9$ \\
\hline $16: 3 n-4$ & $9.3 \pm 0.3$ & $5.4 \pm 0.1^{*}$ & $0.3 \pm 0.4$ & $1.7 \pm 2.2$ & 2.6 & & $0.1 \pm 0.1$ & $0.1 \pm 0.1$ & $0.2 \pm 0.1$ & $0.1 \pm 0.1$ & $0.3 \pm 0.1$ \\
\hline $16: 04$ & $1.4 \pm 0.1$ & $1.4 \pm 0.1$ & $0.2 \pm 0.1$ & $0.1 \pm 0.1$ & 0.1 & $0.9 \pm 0.1$ & $0.6 \pm 0.8$ & $0.7 \pm 0.1$ & $0.3 \pm 0.1$ & $0.2 \pm 0.1$ & $0.2 \pm 0.1$ \\
\hline $18: 2 n-6$ & $0.2 \pm 0.1$ & $0.2 \pm 0.1$ & $1.2 \pm 0.1$ & $0.4 \pm 0.1$ & 0.4 & $15.6 \pm 0.6$ & $3.5 \pm 0.1^{*}$ & $2.3 \pm 0.1 *$ & $4.8 \pm 0.3$ & $2.1 \pm 0.1 *$ & $3.1 \pm 0.1^{*}$ \\
\hline $18: 3 n-6$ & $0.1 \pm 0.1$ & $0.1 \pm 0.1$ & $2.9 \pm 0.1$ & $1.3 \pm 0.1^{*}$ & 0.9 & $0.9 \pm 0.1$ & $0.3 \pm 0.1$ & $0.1 \pm 0.1$ & $0.9 \pm 0.1$ & $0.7 \pm 0.1$ & $0.5 \pm 0.1$ \\
\hline $20: 3 n-6$ & & & $0.5 \pm 0.1$ & $0.1 \pm 0.1$ & 0.1 & & & & $2.7 \pm 0.2$ & $0.5 \pm 0.1$ & $0.3 \pm 0.1$ \\
\hline $20: 4 n-6$ & $0.1 \pm 0.1$ & $0.1 \pm 0.1$ & $15.0 \pm 0.3$ & $2.3 \pm 0.1^{*}$ & 2.6 & $1.4 \pm 0.1$ & $1.9 \pm 0.1$ & $2.8 \pm 0.1^{*}$ & $11.3 \pm 1.1$ & $8.5 \pm 0.1 *$ & $6.1 \pm 0.2 *$ \\
\hline $18: 3 n-3$ & $0.4 \pm 0.1$ & $0.2 \pm 0.1$ & $0.2 \pm 0.1$ & $0.1 \pm 0.1$ & & $8.4 \pm 0.1$ & $7.3 \pm 0.1$ & $4.0 \pm 0.1^{*}$ & $0.9 \pm 0.1$ & $1.1 \pm 0.1$ & $1.0 \pm 0.1$ \\
\hline $18: 4 n-3$ & $1.1 \pm 0.1$ & $0.9 \pm 0.1$ & $0.7 \pm 0.1$ & $0.8 \pm 0.1$ & 0.4 & $10.2 \pm 0.2$ & $16.6 \pm 0.1^{*}$ & $12.0 \pm 0.2$ & $0.1 \pm 0.1$ & $0.1 \pm 0.1$ & $0.2 \pm 0.2$ \\
\hline $20.4 n-3$ & & $0.2 \pm 0.2$ & & $0.1 \pm 0.1$ & & $0.1 \pm 0.1$ & $0.1 \pm 0.1$ & & $0.1 \pm 0.1$ & & \\
\hline $20: 5 n-3$ & $20.5 \pm 0.4$ & $12.5 \pm 0.3^{*}$ & $16.5 \pm 0.1$ & $9.1 \pm 0.1 *$ & 7.4 & $0.5 \pm 0.1$ & $0.7 \pm 0.1$ & $0.4 \pm 0.3$ & $49.6 \pm 1.4$ & $48.2 \pm 1.1$ & $38.4 \pm 4.9$ \\
\hline $22: 5 n-3$ & $0.7 \pm 0.9$ & & & & & & & & & & \\
\hline $22: 6 n-3$ & $1.4 \pm 0.1$ & $0.9 \pm 0.1$ & $2.2 \pm 0.1$ & $1.3 \pm 0.1$ & 0.9 & $10.8 \pm 1.2$ & $13.8 \pm 0.3$ & $15.4 \pm 0.3^{*}$ & & & \\
\hline $\mathrm{EPA}+\mathrm{DHA}$ & $21.8 \pm 0.4$ & $13.4 \pm 0.1 *$ & $18.7 \pm 0.1$ & $10.3 \pm 0.1 *$ & 8.3 & $11.2 \pm 3.2$ & $14.5 \pm 0.3$ & $15.8 \pm 1.1$ & $49.6 \pm 1.4$ & $48.2 \pm 1.1$ & $38.4 \pm 4.9$ \\
\hline
\end{tabular}

20:4 n-6 and lower percentage of 20:5 n-3, whereas the rest of the fatty acids remained relatively constant with reduced growth rates (Table 2). Tisochrysis lutea's relative content of 16:1 and 18:2 n-6 increased, while its content of 16:0 (not significant) and 22:6 n-3 decreased, when the growth rate was reduced. Reduced growth rate of $N$. oculata yielded increased content of 16:0 and 18:1, whereas the relative content of 20:5n-3 was reduced.

These findings show that 14:0 and 16:0 were the main saturated fatty acids, and 16:1 was the main unsaturated fatty acid. The content of polyunsaturated fatty acids varied between the species investigated, with high content of EPA (20:5 n-3) in C. muelleri, C. calcitrans, and $N$. oculata, and high content of DHA (22:6 n-3) in T. lutea. Both C. muelleri and N. oculata had high content of 20:4 n-6 (AA), at 4.4-10.7\% and 6.0-7.3\%, respectively.

For all species investigated, reduced growth rates led to a general lower relative content of the polyunsaturated fatty acids 20:5 n-3 and 22:6 n-3 (Table 2). However, the relative content of 20:4 n-6 was not influenced in the same manner, being constant in $N$. oculata and increasing in $C$. muelleri with decreasing growth rates.

\section{Content of carbohydrates and $\beta$-glucans}

The total carbohydrates in the microalgae varied from $54 \mathrm{mg} \mathrm{g}^{-1}$ DW (for T. lutea at $40 \%$ relative specific growth rate) to $235 \mathrm{mg} \mathrm{g}^{-1} \mathrm{DW}$ (for $C$. muelleri at $4 \%$ relative specific growth rate) (Fig. 5). The total carbohydrate content varied with the change in the relative growth rate to a different extent in the different microalgae species. C. mиelleri was the only species that yielded significantly increased content with reduced growth rate. The carbohydrate content of $C$. calcitrans and $N$. oculata did not vary significantly with the growth rate, and T. lutea had highest carbohydrate content at the highest growth rate ( $p<0.05$; Fig. 5).

The $\beta$-glucan content varied greatly between species, being highest in $C$. calcitrans and $C$. muelleri, and somewhat lower in T. lutea (Fig. 5). Nannochloropsis oculata had very low $\beta$-glucan content compared to the other microalgae 
Table 2 Fatty acid content ( $\%$ of sum) in microalgae grown at different relative growth rate $\left(4 \% .40 \%\right.$, and $60 \%$ of $\mu_{\text {max }}$ ). Mean \pm SE of two or three replicates $(C$. muelleri at $60 \%$ only $n=1)$. Open is not detected or $<0.1$. Asterisks indicate significant difference within species

\begin{tabular}{|c|c|c|c|c|c|c|c|c|c|c|c|}
\hline \multirow[t]{3}{*}{ Fatty acid } & \multirow{2}{*}{\multicolumn{2}{|c|}{$\frac{\text { Bacillariophyceae }}{\text { C. calcitrans }}$}} & \multirow{2}{*}{\multicolumn{3}{|c|}{ C. muelleri }} & \multicolumn{3}{|c|}{ Prymnesiophyceae } & \multicolumn{3}{|c|}{ Eustigmatophyceae } \\
\hline & & & & & & \multicolumn{3}{|l|}{ T. lutea } & \multicolumn{3}{|l|}{ N. oculata } \\
\hline & $40 \%$ & $60 \%$ & $4 \%$ & $40 \%$ & $60 \%$ & $4 \%$ & $40 \%$ & $60 \%$ & $4 \%$ & $40 \%$ & $60 \%$ \\
\hline $14: 00$ & $10.7 \pm 2.9$ & $8.5 \pm 0.1$ & $8.4 \pm 0.4$ & $9.1 \pm 0.5$ & 7.2 & $16.7 \pm 3.2$ & $15.3 \pm 1.2$ & $14.1 \pm 1.8$ & $6.3 \pm 0.1$ & $4.8 \pm 0.3$ & $5.6 \pm 0.5$ \\
\hline $16: 00$ & $11.9 \pm 2.7$ & $13.2 \pm 0.3$ & $24.9 \pm 1.7$ & $21.5 \pm 2.1$ & 20 & $1.4 \pm 0.1$ & $5.6 \pm 5.8$ & $10.9 \pm 0.1$ & $21.3 \pm 3.2$ & $16.3 \pm 0.1 *$ & $17.1 \pm 0.8^{*}$ \\
\hline $18: 00$ & $0.3 \pm 0.1$ & $0.4 \pm 0.1$ & $1.8 \pm 0.1$ & $1.9 \pm 0.1$ & 1.3 & $0.2 \pm 0.1$ & $5.2 \pm 7.1$ & $0.4 \pm 0.1$ & $0.5 \pm 0.1$ & $0.2 \pm 0.1$ & $0.2 \pm 0.1$ \\
\hline 20:00 & $0.1 \pm 0.1$ & $0.1 \pm 0.1$ & $0.1 \pm 0.1$ & $0.2 \pm 0.1$ & & $0.1 \pm 0.1$ & $0.1 \pm 0.1$ & $0.1 \pm 0.1$ & & & \\
\hline 22:00 & & $0.1 \pm 0.1$ & & & & $0.1 \pm 0.1$ & & & & & \\
\hline 16:01 & $17.8 \pm 1.8$ & $29.4 \pm 2.0^{*}$ & $30.2 \pm 1.4$ & $28.7 \pm 2.3$ & 33.7 & $14.9 \pm 0.1$ & $9.3 \pm 1.9 *$ & $4.7 \pm 0.6^{*}$ & $21.8 \pm 2.2$ & $22.9 \pm 1.1$ & $23.7 \pm 1.4$ \\
\hline $18: 1 \mathrm{n}-9$ & $0.5 \pm 0.2$ & $0.7 \pm 0.1$ & $0.9 \pm 0.1$ & $0.8 \pm 0.1$ & 0.7 & $12.7 \pm 0.3$ & $5.7 \pm 5.3$ & $12.1 \pm 0.1$ & $5.8 \pm 0.7$ & $1.3 \pm 0.1 *$ & $2.2 \pm 0.1 *$ \\
\hline $18: 1 \mathrm{n}-7$ & $1.4 \pm 0.3$ & $1.7 \pm 0.0$ & $1.8 \pm 0.1$ & $1.0 \pm 0.1$ & 0.7 & $2.2 \pm 0.1$ & $1.2 \pm 1.4$ & $1.7 \pm 0.1$ & $0.9 \pm 0.3$ & $0.6 \pm 0.1$ & $0.6 \pm 0.1$ \\
\hline $22: 01$ & & $0.1 \pm 0.1$ & $0.4 \pm 0.0$ & $0.1 \pm 0.1$ & & & & & & & \\
\hline $16: 2 n-4$ & $4.4 \pm 1.2$ & $3.7 \pm 0.1$ & $3.3 \pm 1.4$ & $3.9 \pm 2.7$ & 1.8 & $0.6 \pm 0.1$ & $1.3 \pm 0.1$ & $0.9 \pm 0.1$ & $0.4 \pm 0.1$ & $1.0 \pm 0.1$ & $0.9 \pm 1.0$ \\
\hline $16: 3 n-4$ & $14.1 \pm 3.5$ & $10.4 \pm 0.1$ & $0.2 \pm 0.3$ & $3.3 \pm 4.4$ & 5.8 & & $0.1 \pm 0.1$ & $0.1 \pm 0.1$ & $0.1 \pm 0.1$ & $0.1 \pm 0.1$ & $0.2 \pm 0.1$ \\
\hline $16: 04$ & $2.1 \pm 0.6$ & $2.6 \pm 0.1$ & $0.1 \pm 0.1$ & $0.1 \pm 0.1$ & 0.2 & $0.9 \pm 0.1$ & $0.7 \pm 0.9$ & $0.9 \pm 0.1$ & $0.2 \pm 0.1$ & $0.2 \pm 0.1$ & $0.2 \pm 0.1$ \\
\hline $18: 2 n-6$ & $0.3 \pm 0.1$ & $0.4 \pm 0.1$ & $0.9 \pm 0.1$ & $0.8 \pm 0.1$ & 0.9 & $16.4 \pm 0.8$ & $4.4 \pm 0.3^{*}$ & $3.4 \pm 0.1 *$ & $2.9 \pm 0.4$ & $1.8 \pm 0.1$ & $3.1 \pm 0.2$ \\
\hline $18: 3 n-6$ & $0.2 \pm 0.0$ & $0.1 \pm 0.1$ & $2.1 \pm 0.1$ & $2.5 \pm 0.2$ & 2 & $0.9 \pm 0.1$ & $0.4 \pm 0.1$ & $0.1 \pm 0.1$ & $0.5 \pm 0.1$ & $0.6 \pm 0.1$ & $0.5 \pm 0.1$ \\
\hline $20: 3 n-6$ & & & $0.4 \pm 0.1$ & $0.2 \pm 0.1$ & 0.2 & & & $0.1 \pm 0.1$ & $1.6 \pm 0.3$ & $0.4 \pm 0.0$ & $0.3 \pm 0.1$ \\
\hline $20: 4 n-6$ & $0.2 \pm 0.1$ & $0.2 \pm 0.1$ & $10.7 \pm 0.4$ & $4.4 \pm 0.6^{*}$ & 5.8 & $1.5 \pm 0.2$ & $2.4 \pm 0.1$ & $4.0 \pm 0.1$ & $6.9 \pm 1.3$ & $7.3 \pm 0.2$ & $6.1 \pm 0.5$ \\
\hline $18: 3 n-3$ & $0.6 \pm 0.1$ & $0.4 \pm 0.1$ & $0.1 \pm 0.1$ & $0.2 \pm 0.1$ & & $8.8 \pm 0.2$ & $9.2 \pm 0.4$ & $5.8 \pm 0.1$ & $0.5 \pm 0.1$ & $0.9 \pm 0.1$ & $1.0 \pm 0.1$ \\
\hline $18: 4 n-3$ & $1.7 \pm 0.4$ & $1.7 \pm 0.0$ & $0.5 \pm 0.1$ & $1.5 \pm 0.1$ & 0.9 & $10.7 \pm 0.3$ & $20.9 \pm 1.4^{*}$ & $17.4 \pm 0.1^{*}$ & & $0.1 \pm 0.1$ & $0.2 \pm 0.2$ \\
\hline $20.4 n-3$ & & $0.3 \pm 0.4$ & & $0.2 \pm 0.1$ & & $0.1 \pm 0.1$ & $0.1 \pm 0.1$ & & $0.1 \pm 0.1$ & & \\
\hline $20: 5 n-3$ & $31.0 \pm 7.3$ & $24.3 \pm 0.5$ & $11.7 \pm 0.7$ & $17.3 \pm 1.5^{*}$ & 16.6 & $0.5 \pm 0.1$ & $0.9 \pm 0.1$ & $0.6 \pm 0.4$ & $30.1 \pm 1.9$ & $41.6 \pm 0.5^{*}$ & $38.2 \pm 0.3^{*}$ \\
\hline $22: 5 n-3$ & $0.8 \pm 1.2$ & & & & & & & $0.1 \pm 0.1$ & & & \\
\hline $22: 6 n-3$ & $2.1 \pm 0.6$ & $1.7 \pm 0.3$ & $1.5 \pm 0.1$ & $2.4 \pm 0.1$ & 2 & $11.3 \pm 1.4$ & $17.4 \pm 1.4^{*}$ & $22.5 \pm 0.4^{*}$ & & & \\
\hline $\mathrm{EPA}+\mathrm{DHA}$ & $33.1 \pm 7.9$ & $26.0 \pm 0.8$ & $13.2 \pm 0.8$ & $19.7 \pm 1.6^{*}$ & 18.6 & $11.8 \pm 1.5$ & $18.3 \pm 1.5^{*}$ & $23.1 \pm 0.8^{*}$ & $30.1 \pm 1.9$ & $41.6 \pm 0.5^{*}$ & $38.2 \pm 0.3^{*}$ \\
\hline
\end{tabular}

Fig. 5 Content of total carbohydrates and $\beta$-glucans of the microalgae cultivated by semicontinuous culture at different relative growth rates $(4 \%, 40 \%$, and $60 \%$ of $\mu_{\max }$ ). Means with SE bars $(n=3)$. Asterix indicate significant differences $(p<0.05)$

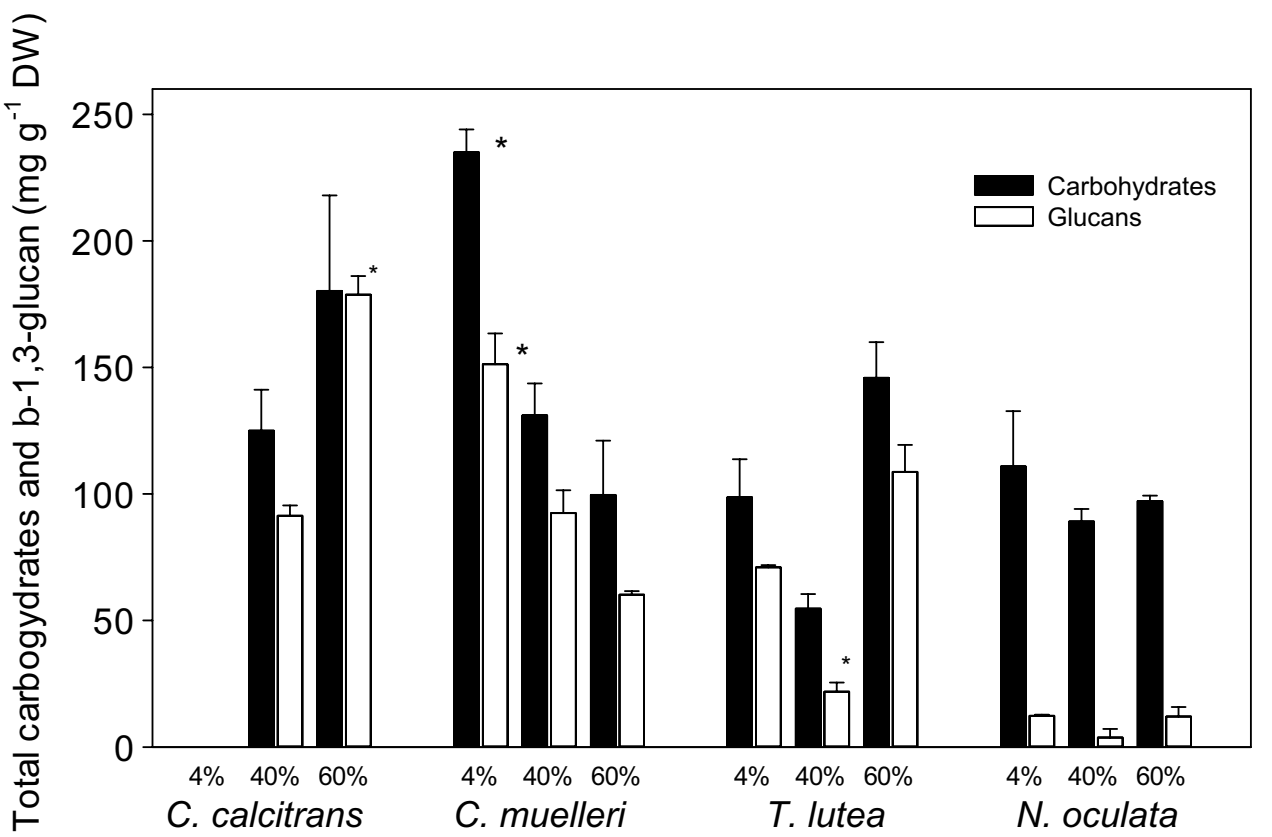


species investigated. As for total carbohydrates, only in $C$. muelleri, the $\beta$-glucan content increased with the reduced relative growth rate.

\section{Productivity of lipids, EPA, DHA, carbohydrates, and $\beta$-glucans}

The productivity of total lipids in all species investigated varied with the relative growth rate and was highest when the algae were cultivated at $40 \%$ of the maximum specific growth rate (Fig. 6). Highest production yield of lipids was found in T. lutea cultivated at $40 \%$ relative growth rate, with $14 \mathrm{mg}$ total lipid $\mathrm{L}^{-1}$ culture volume per day.

Similarly to the total lipids, highest production yield of both EPA and DHA was obtained when the algae were cultivated at $40 \%$ relative growth rate (Fig. 6). The highest production yield of EPA was found in N. oculata at $40 \%$ relative growth rate, with $1.7 \mathrm{mg} \mathrm{L}^{-1}$ culture volume per day. The highest production yield of DHA was found in $T$. lutea at $40 \%$ relative growth rate, with $0.8 \mathrm{mg} \mathrm{L}^{-1}$ culture volume per day.

The production yield of total carbohydrates and $\beta$-glucans varied with the species and the growth rate
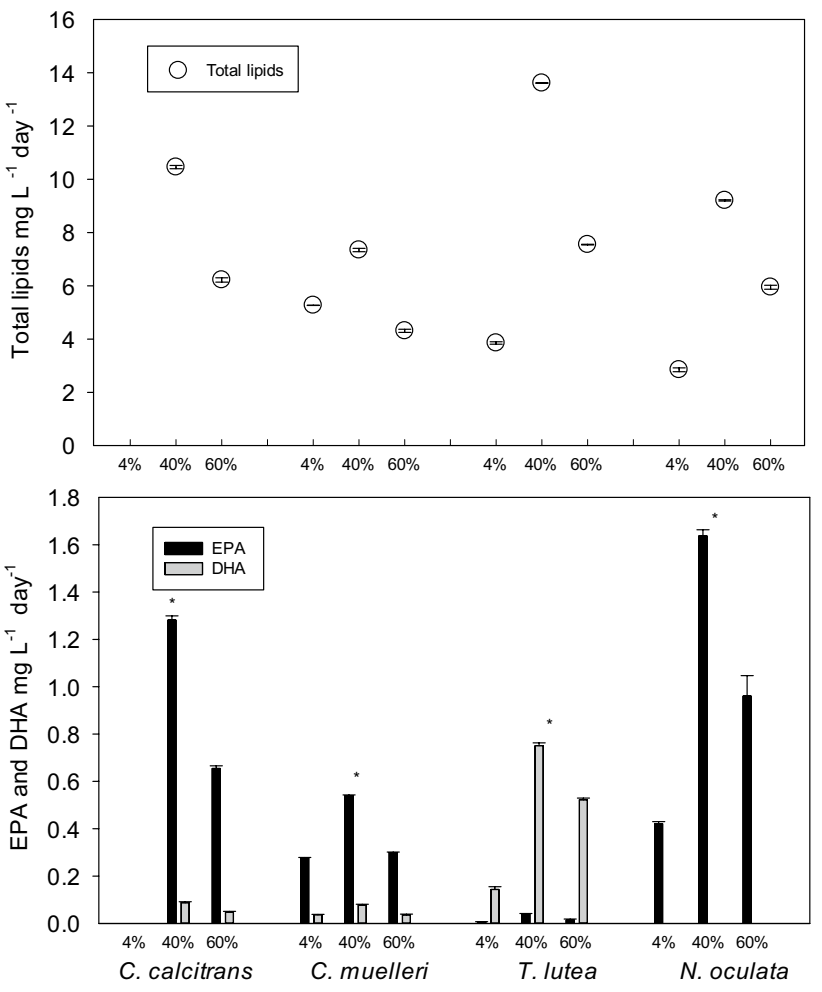

Fig. 6 Production yields ( $\mathrm{mg} \mathrm{L}^{-1}$ culture volume day ${ }^{-1}$ ) of total lipids (upper panel), and EPA and DHA (lower panel) of the microalgae cultivated at different relative growth rates $(4 \%, 40 \%$, and $60 \%$ of $\left.\mu_{\max }\right)$. Means with SE bars $(n=2-3)$. Asterisks indicate significant differences $(p<0.05)$
(Fig. 7). The two diatoms, C. calcitrans and C. muelleri, showed different patterns of production yields of total carbohydrates and $\beta$-glucans with different relative growth rates. Chaetoceros calcitrans obtained similar total carbohydrate content at 40 and $60 \%$ relative growth rates, while C. muelleri got significant highest production yield of both total carbohydrates and $\beta$-glucans at medium $(40 \%)$ relative growth rate, and lower yields at $4 \%$ and $60 \%$. A similar pattern was observed for total carbohydrates in $\mathrm{N}$. oculata as well, with the highest yield at $40 \%$ relative growth rate. T. lutea had an increased yield of both total carbohydrates and $\beta$-glucans with increasing relative growth rates.

\section{Discussion}

The growth rates of microalgae are species-specific and also to a large extent depend on the cultivation conditions. Besides nutrients and light, temperature has been found to have a pronounced effect on the growth of microalgae, as shown in the present study. Most of the seven marine microalgae species grew between 16 and $24{ }^{\circ} \mathrm{C}$, except for $C$. calcitrans. This is consistent with previous studies, which found that most microalgae species can tolerate a wide range of temperature between 15 and $30{ }^{\circ} \mathrm{C}$ (Ras et al. 2013; Chaisutyakorn et al. 2018). The maximum specific growth rate varied with the species and cultivation temperature. Out of the seven species investigated, $S$. costatum showed the highest specific growth, followed by Tetraselmis sp., indicating the great potential of these two species for commercial production. The optimal temperatures for the two diatoms (C. calcitrans and C. muelleri) were found to be 16 and $24{ }^{\circ} \mathrm{C}$, respectively, with specific growth rates at 1.6 and $2.1 \mathrm{day}^{-1}$, respectively. These values are much higher than those found in a previous study for Chaetoceros sp. $\left(0.54 \mathrm{day}^{-1}\right)$ (Chaisutyakorn et al. 2018). Tisochrysis lutea was found to grew best at $24{ }^{\circ} \mathrm{C}$, in agreement with Renaud et al. (1995), who found that the optimal temperature for T. lutea was $25{ }^{\circ} \mathrm{C}$. In the present study, the highest specific growth rate was 1.73 day $^{-1}$, twice the value reported by Renaud et al. (1995). The optimal temperature for $N$. oculata was $16{ }^{\circ} \mathrm{C}$, while other studies showed that $N$. oculata grew best at $20-25{ }^{\circ} \mathrm{C}$ (Converti et al. 2009; Wei et al. 2015; Chaisutyakorn et al. 2018). This indicates that the adaptability to temperature conditions may vary even within the same microalgae species. $N$. oculata showed a lower specific growth rate compared to other six species; however, this value is still much higher than those reported by Converti et al. (2009) and Chaisutyakorn et al. (2018) $\left(0.13-0.33 \mathrm{day}^{-1}\right)$. The growth rate of the species was also found to affect the productivity of the species (Converti et al. 2009); therefore, choosing the optimal cultivation 
Fig. 7 Production yields of total carbohydrates and $\beta$-glucans (mg L ${ }^{-1}$ culture volume day ${ }^{-1}$ ) of the microalgae cultivated at different relative growth rates $\left(4 \%, 40 \%\right.$, and $60 \%$ of $\left.\mu_{\max }\right)$. Means with SE bars $(n=3)$. Asterisks indicate significant differences $(p<0.05)$

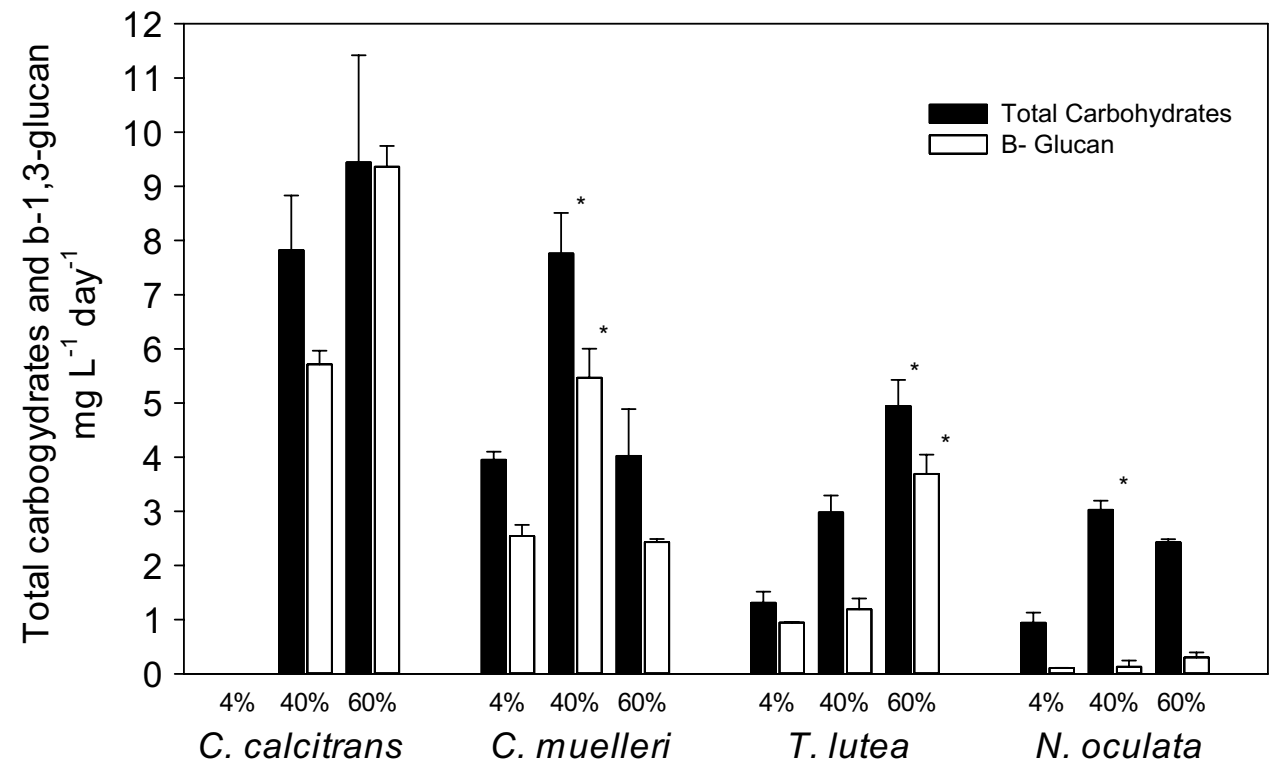

temperature for the strain of species is important for the production yield of the culture.

The cellular content of carbon and nitrogen varied with the density of the culture for all species investigated in this study, in agreement with earlier studies (PérezMorales et al. 2015; Roopnarain et al. 2015). The N/C, $\mathrm{P} / \mathrm{C}$, and N/P ratios for the microalgae cells in the stationary phase in the present study were lower than what could be expected for nitrogen- and phosphorus-saturated cells (Sakshaug et al. 1983; Sakshaug and Olsen, 1986). The N/P ratio (by weight) of the growth medium used was 11 (F/2: Guillard and Ryther 1962), with corresponding values of the microalgae cells in the stationary phase (ranging 11-18) above the ratios for oceanic particulate matter, called the Redfield ratio (N/P $=7.1$ by weight, Redfield et al. 1963). This indicates that the algae cultures in the present study were nutrient-limited and limited more by phosphorus than by nitrogen. The decreasing N/C ratio with increasing cell numbers was probably a result of constant lipid and carbohydrate synthesis, together with reduced protein synthesis due to exhaustion of nutrients in the growth media (Siron et al. 1989; Sukenik and Livne, 1991). The N/C ratio of $N$. oculata behaved differently from that of the other species, increasing up to a certain density, and then decreasing with further cellular density increases. Similar results were reported by Flynn et al. (1993), suggesting that this species can assimilate and store available nitrogen.

The total lipid content of the algae species investigated varied between 10 and 34\% of dry matter, and all species obtained increased lipid content with reduced relative growth rates due to nutrient limitation. This is in agreement with earlier reports (Reitan et al. 1994; Brown et al. 1997;
Shokravi et al. 2020). The highest lipid content was found in $N$. oculata grown at $4 \%$ relative growth rate, followed by $C$. muelleri and $T$. lutea, both also at $4 \%$ relative growth rate. The lipid accumulation in the species investigated can be a result of reduced cell division and protein synthesis due to reduced availability of nutrients, as well as of increased neutral lipid synthesis when the algae became nutrient-limited (Sukenik and Livne 1991; Lombardi and Wangersky 1995; Wang et al. 2019). This indicates the great potential of using these three species for lipid production under nutrient limitation.

The content of n-3 PUFA in microalgae is of great interest when searching for aquafeed resources (Chauton et al 2014). The fatty acid profiles of the species investigated showed relatively close taxonomic similarities, where the two diatom species (C. calcitrans and C. muelleri) obtained high content of 20:5 n-3, T. lutea had high content of 22:6n-3; and $N$. oculata was rich in 20:5 n-3. Our results show that out of the species investigated, only $T$. lutea can be considered a source of DHA (22:6n-3), with a quantitative DHA content of 11 to $15 \mathrm{mg} \mathrm{g}^{-1} \mathrm{DW}$. Our results show that $N$. oculata is a promising species for cultivation for EPA-rich biomass, with $38-50 \mathrm{mg} \mathrm{g}^{-1} \mathrm{DW}$, consistently with earlier reports (Delaunay et al. 1993; Reitan et al. 1994; Zhukova and Aizdaicher 1995).

The change in relative growth rate of the microalgae revealed different effects on the relative content of fatty acids. The per cent content of EPA in $N$. oculata and $C$. muelleri and content of DHA in T. lutea increased with increased relative growth rate.

Much attention has been paid to the content of total carbohydrates and $\beta$-glucans in diatoms (Granum and Myklestad 2002; Chiovitti et al. 2004). In the present study, the highest 
content of total carbohydrates was found in $C$. muelleri, and highest $\beta$-glucans was found in $C$. calcitrans. Among the species investigated, only $C$. muelleri accumulated both carbohydrates and $\beta$-glucans with decreasing relative growth rates. The other species did not accumulate carbohydrates with decreasing relative growth rates, as they had for total lipids, meaning that the accumulation of carbohydrates and that of lipids follow different metabolic pathways. The high content of $\beta$-glucans in $C$. muelleri was also reported by Størseth et al. (2004). $\beta$-glucans are increasingly used as immunostimulants in aquafeed because of their ability to be incorporated directly into aquafeeds and to enhance the immune system in finfish (Bruce and Brown 2017).

Microalgae are considered one of the most promising feedstocks for a sustainable supply of commodities and specialties for both food and non-food production (Singh and Gu 2010; Wijffels et al. 2010; Milledge 2011; Draaisma et al. 2013). Interestingly, all four microalgae species investigated obtained the highest production yield of lipids, calculated as the content of lipids in the culture volume harvested per day, when cultivated at a relative growth rate $40 \%$ of the maximum specific growth rate. High productivity is a key factor when selecting species and cultivation conditions for producing biomass and lipids for use in fish feed and other commodities (Chauton et al. 2014). Microalgae cultivation is increasingly recognised as a suitable technology for the production of the omega-3 PUFA, cultivated both under heterotrophic conditions (Oliver et al. 2020) and under traditional phototrophic conditions as well as photoheterotrophic and mixotrophic culture (Hamilton et al. 2014; Ryckebosch et al. 2014; Piasecka et al. 2020). The production yield of EPA and DHA also varied with the growth rate, and the highest production yield of EPA was found in N. oculata cultivated at $40 \% \mu_{\max }$, whereas the highest production yield of DHA was found in T. lutea cultivated at $40 \% \mu_{\max }$. The Marine Ingredients Organization, IFFO, considers microalgae the most promising and sustainable alternative source of EPA and DHA for fish feed (Chauton et al. 2014). However, the productivity of EPA and DHA from microalgae depends on the biomass production and the fatty acid content in the dry matter of the algae. Therefore, production of EPA and DHA from microalgae is a compromise between maximising the lipid content by modulating growth conditions without lowering biomass production, as discussed by Chauton et al. (2014).

The productivity of carbohydrates and $\beta$-glucans again showed higher values in $C$. muelleri and $N$. oculata when grown at $40 \% \mu_{\max }$, while increasing with increased relative growth rate in $C$. calcitrans and T. lutea. Out of the four species, $C$. calcitrans showed the highest productivity of both carbohydrates and $\beta$-glucans when grown at $60 \% \mu_{\max }$. Based on this result, $C$. calcitrans is a promising microalgae strains for producing $\beta$-glucans as immunostimulants for aquafeed.
Again, it is essential to maximise the carbohydrate content by manipulating the growth conditions without lowering the biomass production to achieve the maximum production of $\beta$-glucans.

\section{Conclusion}

Selected microalgae species belonging to the Bacillariophyceae, Haptophyceae, Eustigmatophyceae, and Prasinophyceae were characterised for cellular content of carbon and nitrogen, as well as production yields of lipids, fatty acids, total carbohydrates and $\beta$-glucans. Cellular content of carbon and nitrogen showed species-specific patterns with increasing cell numbers in the culture. The total lipid content of $C$. muelleri, C. calcitrans, $N$. oculata, and T. lutea increased with reduced relative growth rate in semi-continuous cultures and was highest in N. oculata. However, the highest productivity of lipids was found in T. lutea grown at a growth rate of $40 \%$ of the maximum specific growth rate. The content of polyunsaturated fatty acids varied between the species investigated, with high content of EPA in C. muelleri, C. calcitrans, and N. oculata, and high content of DHA in $T$. lutea. The $\beta$-glucan fraction of the carbohydrates was highest in $C$. muelleri and $C$. calcitrans and was very low in N. oculata. Among the species investigated, $C$. muelleri is a promising strain for $\beta$-glucan production due to its high yield of $\beta$-glucans for cells cultivated at a $40 \%$ relative growth rate.

Acknowledgements This research was carried out at NTNU Department of Biology in Trondheim, Norway.

Author contribution The authors Kjell Inge Reitan (KIR), Gunvor Øie (GO), Håvard Jørgensen (HJ), and Xinxin Wang (XW) have contributed to this paper. Conceptualisation: KIR, GO, and HJ; Methodology: KIR and HJ, Formal Analysis: HJ and GO; Investigation: KIR, HJ, GO, and XW; Resources: KIR; Data Curation: KIR, GO, and HJ; Writing-Original Draft Preparation: KIR and XW; Writing-Review and Editing: KIR and XW; Visualisation: KIR; Supervision: KIR and GO; Project Administration: KIR; Funding Acquisition: KIR.

Funding Open access funding provided by NTNU Norwegian University of Science and Technology (incl St. Olavs Hospital - Trondheim University Hospital). The work was supported by the Norwegian Research Council (project nr 127964/122).

Data Availability The raw data supporting the conclusions of this article will be made available by the authors, without undue reservation, to any qualified researcher.

\section{Declarations}

Conflict of interest The authors declare no competing interests.

Open Access This article is licensed under a Creative Commons Attribution 4.0 International License, which permits use, sharing, adaptation, distribution and reproduction in any medium or format, as long as you give appropriate credit to the original author(s) and the source, 
provide a link to the Creative Commons licence, and indicate if changes were made. The images or other third party material in this article are included in the article's Creative Commons licence, unless indicated otherwise in a credit line to the material. If material is not included in the article's Creative Commons licence and your intended use is not permitted by statutory regulation or exceeds the permitted use, you will need to obtain permission directly from the copyright holder. To view a copy of this licence, visit http://creativecommons.org/licenses/by/4.0/.

\section{References}

Bligh EG, Dyer WJ (1959) A rapid method of total lipid extraction and purification. Can J Biochem Physiol 37:911-917

Brown MR, Jeffrey SW, Volkman JK, Dunstan GA (1997) Nutritional properties of microalgae for mariculture. Aquaculture 151:315-331

Bruce T, Brown M (2017) A review of immune system components, cytokines, and immunostimulants in cultured finfish species. Open J Anim Sci 7:267-288

Burr GS, Barrows FT, Gaylord G, Wolters WR (2011) Apparent digestibility of macronutrients and phosphorus in plant derived ingredients for Atlantic salmon, Salmo salar and Arctic charr, Salvelinus alpinus. Aquac Nutr 17:570-577

Carter CG, Bransden MP, Lewis TE, Nichols PD (2003) Potential of thaustochytrids to partially replace fish oil in Atlantic salmon feed. Mar Biotechnol 5:480-492

Chaisutyakorn P, Praiboon J, Kaewsuralikhit C (2018) The effect of temperature on growth and lipid and fatty acid composition on marine microalgae used for biodiesel production. J Appl Phycol 30:37-45

Chang CF, Chen HY, Su MS, Liao IC (2000) Immunomodulation by dietary B-1,3-glucan in the brooders of the black tiger shrimp Penaeus monodon. Fish Shellfish Immunol 10:505-514

Chauton M, Reitan KI, Norsker NH, Tveterås R, Kleivdal H (2014) A techno-economic analysis of industrial production of marine microalgae as a source of EPA and DHA-rich raw material for aquafeed: research challenges and possibilities. Aquaculture 436:95-103

Chiovitti A, Molino P, Crawford SA, Teng R, Spurck T, Wetherbee $R$ (2004) The glucans extracted with warm water from diatoms are mainly derived from intracellular chrysolaminaran and not extracellular polysaccharides. Eur J Phycol 39:117-128

Chiu SY, Kao CY, Tsai MT, Ong SC, Chen CH, Lin CS (2009) Lipid accumulation and $\mathrm{CO} 2$ utilization of Nannochloropsis oculata in response to CO2 aeration. Bioresour Technol 100:833-838

Converti A, Casazza AA, Ortiz EY, Perego P, Del Borghi M (2009) Effect of temperature and nitrogen concentration on the growth and lipid content of Nannochloropsis oculata and Chlorella vulgaris for biodiesel production. Chem Eng Process Process Intensif 48:1146-1151

Dahlmo RA, Bøgwald J, Ingebrigtsen K, Seljelid R (1996) The immunomodulatory effect of laminaran [ $[(1,3)$-D-glucan] on Atlantic salmon, Salmo salar L., anterior kidney leucocytes after intraperitoneal, peroral and peranal administration. J Fish Dis 19:449-457

Delaunay F, Marty Y, Moala J, Samain JF (1993) The effect of monospecific algal diets on growth and fatty acid composition of Pecten maximus (L.) larvae. J Exp Mar Biol Ecol 173:163-179

Doan TTY, Sivaloganathan B, Obbard JP (2011) Screening of marine microalgae for biodiesel feedstock. Biomass Bioenergy 35:2534-2544

Draaisma RB, Wijffels RH, Slegers PM, Brentner LB, Roy A, Barbosa MJ (2013) Food commodities from microalgae. Curr Opin Biotechnol 24:169-177
Dubois M, Gilles KA, Hamilton JK, Rebes PA, Smith F (1956) Colorometric determination of sugars and related substances. Anal Chem 28:350-356

Flynn KJ, Davidson K, Leftley JW (1993) Carbon-nitrogen relations during batch growth of Nannochloropsis oculata (Eustigmatophyceae) under alternating light and dark. J Appl Phycol 5:465-475

Granum E, Myklestad SM (2002) A simple combined method for determination of $\beta$-1,3-glucan and cell wall polysaccharides in diatoms. Hydrobiologia 477:155-161

Guedes AC, Meireles LA, Amaro HM, Malcata FX (2010) Changes in lipid class and fatty acid composition of cultures of Pavlova lutheri, in response to light intensity. J Am Oil Chem Soc 87:791-801

Guillard RRL, Ryther JH (1962) Studies on marine planktonic diatoms I. Cyclotella nana Hustedt and Detonula confervacea (Cleve) Gran. Can J Microbiol 8:229-239

Hamilton ML, Haslam RP, Napier JA, Sayanova O (2014) Metabolic engineering of Phaeodactylum tricornutum for the enhanced accumulation of omega-3 long chain polyunsaturated fatty acids. Metab Eng 22:3-9

Harrison PJ, Thompson PA, Calderwood GS (1990) Effects of nutrient and light limitation on the biochemical composition of phytoplankton. J Appl Phycol 2:45-56

Kilham S (1978) Nutrient kinetics of freshwater planctonic algae using batch and semicontinous methods. Verh Int Verein Theoret Angew Limnol 21:147-157

Koroleff F (1976) Determination of nutrients. In: Grasshof E, Kremling E (eds) Methods the Seawater Analysis. Verlag Chemie, Weinhein, pp 117-126

Lombardi AT, Wangersky PJ (1995) Particulate lipid class composition of three marine phytoplankters Chaetoceros gracilis, Isochrysis galbana (Tahiti) and Dunaliella tertiolecta grown in batch culture. Hydrobiologia 306:1-6

Milledge J (2011) Commercial application of microalgae other than as biofuels: a brief review. Rev Environ Sci Biotechnol 10:31-41

Myklestad S (1974) Production of carbohydrates by marine planktonic diatoms. I. Comparison of nine different species in culture. J Exp Mar Biol Ecol 15:261-274

Myklestad S, Haug A (1972) Production of carbohydrates by the marine diatom Chaetoceros affinis var. willei (Gran) Hustedt. I. Effect of the concentration of nutrients in the culture medium. J Exp Mar Biol Ecol 9:126-136

Oliver L, Dietrich T, Marañón I, Villarán MC, Barrio RJ (2020) Producing omega-3 polyunsaturated fatty acids: a review of sustainable sources and future trends for the EPA and DHA market. Resources 9:148

Patil V, Reitan KI, Mortensen L, Knudsen G, Kallqvist T, Olsen E, Vogt G, Gislerød HR (2006) Microalgae as source of polyunsaturated fatty acids for aquaculture. Curr Top Plant Biol 6:57-65

Pérez-Morales A, Martínez-López A, Jaime C (2015) Dry weight, carbon, $\mathrm{C} / \mathrm{N}$ ratio, hydrogen, and chlorophyll variation during exponential growth of selected microalgae species used in aquaculture. CICIMAR Oceánides 30:33-43

Pernet F, Tremblay R, Demers E, Roussy M (2003) Variation of lipid class and fatty acid composition of Chaetoceros muelleri and Isochrysis sp. grown in a semicontinuous system. Aquaculture 221:393-406

Piasecka A, Nawrocka A, Wiącek D, Krzemińska I (2020) Agro-industrial by-product in photoheterotrophic and mixotrophic culture of Tetradesmus obliquus: Production of $\omega 3$ and $\omega 6$ essential fatty acids with biotechnological importance. Sci Rep 10:6411

Rainuzzo JR, Reitan KI, Olsen Y (1994) The effect of short and long term lipid enrichment on total lipids, lipid class and fatty acid composition in rotifers. Aquacult Int 2:19-32 
Ras M, Steyer J-P, Bernard O (2013) Temperature effect on microalgae: a crucial factor for outdoor production. Rev Environ Sci Biotechnol 12:153-164

Redfield AC, Ketchum BH, Richards FA (1963) The influence of organisms on the composition of the sea water. In: Hill MN (ed) The Sea, vol 2. Interscience Publishers, New York, pp 26-77

Reitan KI, Rainuzzo JR, Olsen Y (1994) Effect of nutrient limitation on fatty acid and lipid content of marine microalgae. J Phycol 30:972-979

Reitan KI, Rainuzzo JR, Øie G, Olsen Y (1997) Nutritional effects of algae on marine fish larvae. Aquaculture 155:207-221

Renaud SM, Zhou HC, Parry DL, Thinh L-V, Woo KC (1995) Effect of temperature on the growth, total lipid content and fatty acid composition of recently isolated tropical microalgae Isochrysis sp., Nitzschia closterium, Nitzschia paleacea, and commercial species Isochrysis sp. (clone T.ISO). J Appl Phycol 7:595-602

Rodolfi L, Chini Zittelli G, Bassi N, Padovani G, Biondi N, Bonini G, Tredici M (2009) Microalgae for oil: strain selection, induction of lipid synthesis and outdoor mass cultivation in a low-cost photobioreactor. Biotechnol Bioeng 102:100-112

Roleda MY, Slocombe SP, Leakey RJG, Day JG, Bell EM, Stanley MS (2013) Effects of nutrient regimes on biomass and lipid production by six oleaginous microalgae in batch culture employing a two-phase cultivation strategy. Bioresour Technol 129:439-449

Roopnarain A, Sym SD, Gray VM (2015) Time of culture harvest affects lipid productivity of nitrogen-starved Isochrysis galbana U4 (Isochrysidales, Haptophyta). Aquaculture 438:12-16

Ryckebosch E, Bruneel C, Termote-Verhalle R, Goiris K, Muylaert K, Foubert I (2014) Nutritional evaluation of microalgae oils rich in omega-3 long chain polyunsaturated fatty acids as an alternative for fish oil. Food Chem 160:393-400

Sakshaug E, Olsen Y (1986) Nutrient status of phytoplankton blooms in Norwegian waters and algal strategies for nutrient competition. Can J Fish Aquat Sci 43:389-396

Sakshaug E, Andresen K, Myklestad S, Olsen Y (1983) Nutrient status of phytoplankton communities in Norwegian waters (marine, brackish, and fresh) as revealed by their chemical composition. J Plankton Res 5:175-196

Shah MR, Lutzu GA, Alam A, Sarker P, Chowdhury MAK, Parsaeimehr A, Liang Y, Daroch M (2018) Microalgae in aquafeeds for a sustainable aquaculture industry. J Appl Phycol 30:197-213

Shokravi Z, Shokravi H, Chyuan OH, Lau WJ, Koloor SSR, Petrů M, Ismail AF (2020) Improving 'lipid productivity' in microalgae by bilateral enhancement of biomass and lipid contents: a review. Sustainability 12:9083

Singh J, Gu S (2010) Commercialization potential of microalgae for biofuels production. Renew Sustain Energy Rev 14:2596-2610

Siron R, Giusti G, Berland B (1989) Changes in the fatty acid composition of Phaeodactylum tricornutum and Dunaliella tertiolecta during growth and under phosphorus deficiency. Mar Ecol Prog Ser 55:95-100
Skrede A, Mydland LT, Ahlstrøm Ø, Reitan KI, Gislerød HR, Øverland M (2011) Evaluation of microalgae as sources of digestible nutrients for monogastric animals. J Anim Feed Sci 20:131-142

Sørensen M, Berge GM, Reitan KI, Ruyter B (2016) Microalga Phaeodactylum tricornutum in feed for Atlantic salmon (Salmo salar) — effect on nutrient digestibility, growth and utilization of feed. Aquaculture 460:116-123

Størseth TR, Hansen K, Skjermo J, Krane J (2004) Characterization of a $\beta$-D-( $1 \rightarrow 3)$-glucan from the marine diatom Chaetoceros muelleri by high-resolution magic-angle spinning NMR spectroscopy on whole algal cells. Carbohydr Res 339:421-424

Størseth TR, Hansen K, Reitan KI, Skjermo J (2005) Structural characterization of $\beta$-1,3-glucans from different growth phases of the marine diatoms Chaetoceros muelleri and Thalassiosira weissflogii. Carbohydr Res 340:1159-1164

Sukenik A, Livne A (1991) Variations in lipid and fatty acid content in relation to acetyl CoA carboxylase in the marine prymnesiophyte Isochrysis galbana. Plant Cell Physiol 32:371-378

Tacon AGJ (1996) Global trends in aquaculture and aquafeed production. In: International Milling Directory 1996. Turret RAI, Uxbridge pp 90-108

Tzovenis I, De Pauw N, Sorgeloos P (2003) Optimisation of T-ISO biomass production rich in essential fatty acids effect of different light regimes on growth and biomass production. Aquaculture 216:203-222

Vetvicka V, Vannucci L, Sima P (2013) The effects of $\beta$-glucan on fish immunity. N Am J Med Sci 5:580-588

Vu MTT, Douëtte C, Rayner TA, Thoisen CV, Nielsen SL, Hansen BW (2016) Optimization of photosynthesis, growth, and biochemical composition of the microalga Rhodomonas salina: an established diet for live feed copepods in aquaculture. J Appl Phycol 28:1485-1500

Wang X, Fosse HK, Li K, Chauton MS, Vadstein O, Reitan KI (2019) Influence of nitrogen limitation on lipid accumulation and EPA and DHA content in four marine microalgae for possible use in aquafeed. Front Mar Sci 6:95

Wei L, Huang X, Huang Z (2015) Temperature effects on lipid properties of microalgae Tetraselmis subcordiformis and Nannochloropsis oculata as biofuel resources. Chin J Oceanol Limnol 33:99-106

Wijffels RH, Barbosa MJ, Eppink MHM (2010) Microalgae for the production of bulk chemicals and biofuels. Biofuels Bioprod Bioref 4:287-295

Yang ZK, Niu YF, Ma YH, Xue J, Zhang MH, Yang WD, Liu JS, Lu SH, Guan Y, Li HY (2013) Molecular and cellular mechanisms of neutral lipid accumulation in diatom following nitrogen deprivation. Biotechnol Biofuels 6:67

Zhukova NV, Aizdaicher NA (1995) Fatty acid composition of 15 species of marine microalgae. Phytochemistry 39:351-356

Publisher's note Springer Nature remains neutral with regard to jurisdictional claims in published maps and institutional affiliations. 